\title{
PENDEDERAN UDANG VANAME Litopenaeus vannamei DENGAN TEKNOLOGI BIOFLOK UNTUK MENINGKATKAN PERTUMBUHAN DAN EFISIENSI PAKAN
}

\author{
THE NURSERY OF WHITE SHRIMP Litopenaeus vannamei WITH BIOFLOC \\ TECHNOLOGY (BFT) TO INCREASE THE GROWTH AND FEED EFFICIENCY
}

\author{
T.M. Haja Almuqaramah ${ }^{1 *}$, Mia Setiawati' ${ }^{1}$ Nur Bambang Priyoutomo1, \\ dan Irzal Effendi1 ${ }^{2}$ \\ ${ }^{1}$ Departemen Budidaya Perairan, FPIK-IPB, Bogor \\ ${ }^{2}$ Pusat Kajian Sumberdaya Pesisir dan Lautan, LPPM-IPB, Bogor \\ *E-mail: tmmarcom.90@gmail.com
}

\begin{abstract}
White shrimp Litopenaeus vannamei culture in floating cage in the sea have very good prospect to be expanded. This culture requires good quality and quantity of juveniles. The juveniles can be obtained from intensive system of nursery. However, this system has some limitations because the high stocking density and amount of feed increases. Unconsumed feed and shrimp metabolite excretion accumulated in the water, this caused the concentration of nitrogen compounds, especially ammonia in the water increased. Currently, Bio-flocs technology (BFT) was developed to reduce waste shrimp or fish farming activities. The purpose of this research was nursery of white shrimp $\underline{L}$. vannamei with bio-flocs technology to increase the growth and efficiency of feed. The design the research was completely randomized design, consisted of two experimental treatments with three replications. The result of this research showed that shrimps fed in BFT system (B) had growth (9.85\%) and efficiency of feed (37.33\%) higher than that in the control $(K)$. The nursery of white shrimp $\underline{L}$. vannamei with bio-floc technology resulted in significantly higher growth and feed efficiency than the control $(P<0.05)$.
\end{abstract}

Keywords: biofloc technology, feed efficiency, growth, Litopenaeus vannamei

\begin{abstract}
ABSTRAK
Budidaya udang vaname Litopenaeus vannamei di karamba jaring apung (KJA) laut mempunyai prospek yang sangat bagus untuk dikembangkan. Budidaya udang di laut membutuhkan tokolan yang berkualitas dan berkuantitas. Tokolan tersebut diperoleh melalui tahap pendederan menggunakan sistem intensif. Namun sistem tersebut memiliki beberapa kendala karena menggunakan padat tebar tinggi dan pemberian jumlah pakan meningkat. Pakan yang tidak termakan dan hasil eksresi metabolik udang, terakumulasi dalam air sehingga konsentrasi senyawa nitrogen terutama ammonia dalam air meningkat. Saat ini, sistem bioflok (BFT-Bio-flocs technology) mulai dikembangkan untuk mengurangi limbah kegiatan budidaya. Tujuan penelitian ini adalah untuk pendederan udang vaname L. vannamei dengan sistem bioflok untuk meningkatkan pertumbuhan dan efisiensi pakan. Rancangan percobaan yang digunakan adalah rancangan acak lengkap (RAL) dengan 2 perlakuan dan 3 ulangan. Hasil penelitian menunjukan bahwa perlakuan sistem bioflok protein $40 \%$ memiliki laju pertumbuhan yang lebih tinggi $(9,85 \%)$ dan efesiensi pakan $(37,33 \%)$ dibandingkan kontrol. Kegiatan pendederan udang vaname dengan sistem bioflok dapat memberikan pertumbuhan dan efesiensi pakan yang lebih baik dan berbeda signifikan dibandingkan kontrol $(\mathrm{P}<0,05)$.
\end{abstract}

Kata kunci: efisiensi pakan, pertumbuhan, teknologi bioflok, udang vaname

\section{PENDAHULUAN}

Budidaya udang vaname Litopenaeus vannamei memiliki prospek sangat bagus untuk dikembangkan sehingga ketersedian tokolan berkualitas dengan kuantitas yang berkelanjutan sangat diperlukan untuk kegiatan pembesaran. Saat ini, pemanfaatan 
potensi laut untuk kegiatan marinkultur sedang dikembangkan, salah satunya adalah terobosan membudidayakan udang vaname menggunakan sistem keramba jaring apung (KJA) di laut. Hal ini juga sebagai upaya dalam mengatasi kondisi lahan darat yang semakin kompetitif. Kondisi pemeliharaan udang di keramba jaring apung (KJA) membutuhkan benur yang berkualitas dan memiliki daya tahan tubuh yang tinggi. Dalam rangka menjamin ketersediaan tokolan tersebut, dapat diperoleh dari persiapan tokolan melalui tahap pendederan dengan menggunakan sistem intensif. Namun sistem tersebut memiliki beberapa kendala karena menggunakan padat tebar tinggi sehingga meningkatkan jumlah pakan yang diberikan. Dari sejumlah pakan yang diberikan, sebagian tidak dikonsumsi oleh udang, sementara pakan yang dikonsumsi sebagian dikonversi menjadi biomasa udang dan sebagian lagi diekskresikan sebagai ammonia atau dikeluarkan sebagai feses. Hasil limbah dari metabolisme dan sisa pakan yang tidak termakan, mengakibatkan tingginya konsentrasi senyawa nitrogen terutama ammonia dalam air sehingga dapat menjadi toksik bagi udang (Avnimelech dan Ritvo, 2003).

Saat ini, sistem bioflok (BFT-Bioflocs technology) mulai dikembangkan untuk mengurangi limbah kegiatan budidaya (Avnimelech, 2006; Avnimelech, 2007). Sistem bioflok merupakan teknologi budidaya yang didasarkan kepada prinsip asimilasi nitrogen anorganik (amonia, nitrit, dan nitrat) oleh komunitas mikroba (bakteri heterotrof) dalam media budidaya sebagai sumber nutrisi bakteri (De Schryver et al., 2008). Bioflok merupakan suspensi yang terdapat di dalam air yang berupa fitoplankton, bakteri, agregat hidup, bahan organik dan pemakan bakteri (Avnimelech, 2007). Tujuan dikembangkannya sistem bioflok ini adalah untuk memperbaiki dan mengontrol kualitas air budidaya, biosekuriti, membatasi penggunaan air, serta efisiensi penggunaan pakan (Avnimelech, 2012). Flok mikroba ini mengandung nutrisi seperti protein $\quad(19,0-40,6 \%)$, lemak $(0,46-11,6 \%)$, dan abu (7-38,5\%) yang cukup baik bagi ikan/udang budidaya (Tacon, 2000; Ekasari, 2008). Menurut Avnimelech (1999) menyatakan bahwa pada sistem bioflok terdapat bakteri heterotrof yang membentuk flok dapat dimanfaatkan oleh hewan akuatik sehingga terbukti mampu mengurangi nitrogen anorganik dan menggantikan protein pakan. Apabila dalam wadah budidaya udang vaname telah terbentuk flok, diharapkan dapat menghemat pakan buatan yang diberikan, karena flok tersebut dapat digunakan sebagai subsitusi pakan bagi udang vaname yang dibudidayakan. Pendederan udang vaname untuk meningkatkan kinerja pertumbuhan yang baik melalui penggunaan sistem bioflok ini perlu diketahui lebih lanjut. Hal ini diharapkan, pemanfaatan limbah budidaya dan upaya penggunaan pakan lebih efisien sehingga dapat menurunkan biaya produksi. Penelitian ini bertujuan untuk pendederan udang vaname $L$. vannamei dengan sistem bioflok dalam meningkatan pertumbuhan dan efisiensi pakan.

\section{METODE PENELITIAN}

\subsection{Waktu dan Tempat}

Penelitian ini dilaksanakan dari Maret sampai April 2015 dilakukan di Fasilitas Praktek Ilmu Perikanan, Program Diploma, Kampus Gunung Gede, Instititut Pertanian Bogor. Pengukuran parameter kimia dilakukan di Laboratorium Nutrisi Ikan, Departemen Budidaya Perairan, Institut Pertanian Bogor.

\subsection{Prosedur Penelitian \\ 2.2.1. Persiapan Wadah dan Penyediaan Bioflok}

Penelitian dilakukan pada akuarium berukuran 60x40x40 cm. Sebelum digunakan, akuarium dibersihkan dan dilakukan proses sterilisasi menggunakan klorin dengan dosis $100 \mathrm{mg} / \mathrm{L}$ lalu dibilas bersih. Selanjutnya diisi air hingga ketinggi- 
an $30 \mathrm{~cm}$, dengan volume air yang diisikan yaitu $72 \mathrm{~L}$, serta dilengkapi dengan 3 titik aerasi. Bakteri Bacillus sp diberikan satu kali pada hari pertama penelitian dengan dosis 20 $\mathrm{mL} / \mathrm{m}^{3}$ air dengan kepadatan $1 \times 10^{10}$ $\mathrm{CFU} / \mathrm{mL}$. Penambahan sumber karbon eksternal (molase) dilakukan secara langsung ke dalam akuarium pemeliharaan udang dan diberikan sebanyak 1 kali dalam sehari dengan waktu 2 jam setelah pemberian pakan pagi yakni pada pukul 08.00 WIB, dengan estimasi $\mathrm{C} / \mathrm{N}$ rasio 10 . Jumlah karbon yang ditambahkan untuk mendukung proses pembentuk flok oleh bakteri heterotrof pada masing-masing perlakuan menggunakan rumus (De Schryver et al., 2008).

\subsubsection{Pemeliharaan Udang Uji}

Udang vanname PL16 berbobot $0,03 \pm 0,04$ g/ekor dan berukuran 1,60 $\pm 1,69$ $\mathrm{cm} /$ ekor ditebar dengan kepadatan 458 ekor/ $\mathrm{m}^{2}$ atau 110 ekor/akuarium, dipelihara selama 28 hari. Selama pemeliharaan udang, frekuensi pemberian pakan diberikan 4 kali sehari $(06.00,11.00,16.00$ dan 21.00 WIB) dengan tingkat pemberian pakan sebesar $25 \%$. Penelitian terdiri dari 2 perlakuan dengan 3 kali ulangan dengan menggunakan rancangan acak lengkap (RAL).

Tabel 1. Formulasi bahan baku pakan bobot kering pada pakan perlakuan yang digunakan pada pemeliharaan udang vaname Litopenaeus vannamei selama 28 hari masa pemeliharaan.

\begin{tabular}{lc}
\hline \multicolumn{1}{c}{ Bahan } & $(\%)$ \\
\hline Tepung Kepala Udang & 25,00 \\
Tepung Bungkil Kedelai & 20,00 \\
Tepung Pollard & 12,50 \\
Tepung Tapioka & 3,00 \\
Minyak Ikan & 0,50 \\
Minyak Jagung & 1,00 \\
Vitamin-Mix & 5,00 \\
CMC* & 3,00 \\
Jumlah & 100,00 \\
\hline
\end{tabular}

Keterangan: $\mathrm{CMC}^{*}=$ Carboxy Methyl Cellulose, Filler* ${ }^{*}$ Bahan tanpa nutrisi
Penempatan wadah penelitian dilakukan secara acak. Perlakuan yang dicobakan adalah perlakuan $\mathrm{C}=$ Pemberian pakan dengan protein $40 \%$ menggunakan sistem bioflok, perlakuan $\mathrm{K}=$ Pemberian pakan dengan protein $40 \%$ tanpa sistem bioflok sebagai kontrol.

Perlakuan kontrol adalah perlakuan yang tidak ditambahkan sumber karbon eksternal (molase) ke dalam wadah perlakuan. Pada perlakuan kontrol juga dilakukan penyiponan setiap tiga hari sekali.

Tabel 2. Komposisi proksimat pakan perlakuan yang digunakan pada pemeliharaan udang vaname Litopenaeus vannamei selama 28 hari masa pemeliharaan.

\begin{tabular}{ll}
\hline \multicolumn{1}{c}{ Parameter } & $\begin{array}{c}\text { Hasil Proksimat } \\
(\%)\end{array}$ \\
\hline Kadar Abu & 13,96 \\
Protein & 39,90 \\
Lemak & 5,20 \\
Serat Kasar & 2,42 \\
BETN* & 38,51 \\
C/P Ratio (kkal GE/g ) & 10,02 \\
Energi Total (kkal/g) & 4020,60 \\
\hline Keterangan: BETN* = Bahan ekstrak tanpa \\
\multicolumn{2}{c}{ nitrogen. }
\end{tabular}

\subsection{Parameter Uji dan Analisis Data}

Pengumpulan data bobot dan panjang udang dilakukan saat sampling setiap 7 hari sekali, sedangkan jumlah udang yang hidup dihitung pada sampling terakhir. Hasil sampling bobot dan panjang menjadi dasar penentuan jumlah pakan yang diberikan setiap harinya dengan mengasumsikan tingkat kelangsungan hidup pada minggu sampling tersebut. Parameter uji yang diukur meliputi total suspended solids (TSS), volatile suspended solids (VSS), volume flok, nutrien flok, dan kinerja pertumbuhan udang yang meliputi panjang relatif, laju pertumbuhan harian (LPH), efisiensi pakan, tingkat kelangsungan hidup (TKH), retensi 
protein dan retensi lemak yang dihitung pada akhir pengamatan (pada hari ke 28).

\subsubsection{Total Suspended Solid (TSS)}

Kertas saring sejumlah sampel dikeringkan dalam oven selama 24 jam lalu didinginkan dalam desikator dan ditimbang (X1). Sebanyak $50 \mathrm{~mL}$ air sampel disaring dengan millipore $0,45 \mu \mathrm{m}$ kemudian cawan keramik disiapkan dan dioven selama 24 jam lalu didinginkan dalam desikator dan ditimbang. Kertas saring lalu ditempatkan ke dalam cawan keramik, dioven pada suhu $100^{\circ} \mathrm{C}$ selama $24 \mathrm{jam}$, kemudian didinginkan dalam desikator lalu ditimbang (X2). TSS dihitung berdasarkan Metode Standar APHA (2005) sebagai berikut :

$\mathrm{TSS}(\mathrm{mg} / \mathrm{L})=\frac{(X 2-X 1)}{\text { Volume Sampel Air }} \times 1000$.

\subsubsection{Volatile Suspended Solid (VSS)}

Sampel dari pengukuran TSS yang sudah ditimbang (X2) dimasukkan ke dalam tanur pada suhu $600^{\circ} \mathrm{C}$ selama 2 jam. Masing masing cawan lalu dikeluarkan dari tanur, didinginkan dalam desikator kemudian ditimbang (X3). VSS dapat dihitung berdasarkan Metode Standar APHA (2005) sebagai berikut :

$\operatorname{VSS}(\mathrm{mg} / \mathrm{L})=\frac{(X 3-X 2)}{\text { Volume Sampel Air }} \times 1000$

\subsubsection{Volume Flok}

Volume flok merupakan reprentasi dari kepadatan partikel flok dalam suatu kolom air Avnimelech (2012). Sebanyak 50 ml. sampel air diendapkan selama 30 menit dalam tabung conical bervolume $50 \mathrm{~mL}$. Volume flok yang mengendap dicatat dan selanjutnya dihitung dengan rumus :

Volume flok $(\mathrm{mL} / \mathrm{L})=\frac{\text { Volume Endapan }}{\text { Volume Sampel Air }} \times 1000$

\subsubsection{Komposisi Nutrien Flok}

Komposisi nutrien flok diketahui melalui analisis proksimat bioflok yang meliputi kadar protein, lemak, abu, dan serat kasar dilakukan pada awal, tengah dan akhir penelitian. Nutrien flok diukur dengan menggunakan metode Takeuchi (1988).

\subsubsection{Pertumbuhan Relatif}

Panjang relatif (PR) adalah presentase pertambahan udang setiap hari selama penelitian. Panjang relatif dihitung dengan menggunakan rumus (Acarli and Lok, 2008):

$\mathrm{PR}=\frac{\ln \mathrm{Lt}-\ln \mathrm{L} 0}{\mathrm{t}}$

Keterangan: $\mathrm{PR}=$ Panjang Relatif (\%), $\mathrm{Lt}=$ Panjang rata-rata ikan pada akhir penelitian $(\mathrm{cm})$, Lo $=$ Panjang rata-rata ikan pada awal penelitian $(\mathrm{cm}), \mathrm{T}=$ Lama waktu pemeliharaan (hari)

\subsubsection{Laju Pertumbuhan Harian}

Laju pertumbuhan harian $(\alpha)$ adalah presentase pertambahan udang setiap hari selama penelitian. Laju pertumbuhan harian udang dihitung dengan menggunakan rumus (Huisman, 1987) sebagai berikut:

$$
\alpha(\% / \text { hari? })=\left[\sqrt[n]{\frac{\overline{w t}}{w_{0}}}-1\right] \times 100
$$

Keterangan: $\alpha=$ Laju Pertumbuhan Harian $\%$, Wo $=$ Bobot tubuh rata-rata pada awal pemeliharaan $(\mathrm{g}), \mathrm{Wt}=$ Bobot tubuh ratarata pada akhir pemeliharaan $(\mathrm{g}), \mathrm{n}=$ Lama waktu pemeliharaan.

\subsubsection{Efisiensi Pakan}

Efisiensi pakan merupakan perbandingan biomassa udang dengan jumlah pakan yang diberikan selama masa pemeliharaan. Efisiensi pakan dapat dihitung dengan menggunakan rumus Takeuchi (1988):

$E P=\frac{(w t+w d)-w 0}{F} \times 100$

Keterangan: $\mathrm{EP}=$ Efisiensi Pakan \%, $\mathrm{F}=$ Jumlah pakan yang diberikan selama pemeliharaan $(\mathrm{g})$. 
$\mathrm{Wt}=$ Bobot total udang pada akhir pemeliharaan $(\mathrm{g})$, Wo $=$ Bobot total udang pada awal pemeliharaan $(\mathrm{g}), \mathrm{Wd}=$ Bobot total udang mati $(\mathrm{g})$.

\subsubsection{Tingkat Kelangsungan Hidup}

Tingkat kelangsungan hidup (TKH) adalah perbandingan jumlah ikan yang hidup sampai akhir pemeliharaan dengan jumlah ikan pada awal pemeliharaan, yang dihitung menggunakan rumus dari Goddard (1996) yaitu:

$\mathrm{TKH}(\%)=\frac{\mathrm{Nt}}{\mathrm{No}} \times 100$

Keterangan: $\mathrm{TKH}=$ Tingkat kelangsungan hidup (\%), $\mathrm{N}_{\mathrm{t}}=$ Jumlah ikan hidup pada akhir pemeliharaan (ekor), $\mathrm{N}_{\mathrm{o}}=$ Jumlah ikan pada awal pemeliharaan (ekor).

\subsubsection{Retensi Protein}

Nilai Retensi Protein dapat dihitung dengan menggunakan rumus Watanabe et al. (2001):

$\mathrm{RP}(\%)=[(\mathrm{F}-\mathrm{I}) / \mathrm{P}] \times 100$

Keterangan: $\mathrm{RP}=$ Retensi Protein $(\%), \mathrm{F}=$ Jumlah protein tubuh udang pada akhir pemeliharaan $(\mathrm{g}), \mathrm{I}=$ Jumlah protein tubuh udang pada awal pemeliharaan $(\mathrm{g})$, dan $\mathrm{P}=$ Jumlah protein udang yang dikonsumsi selama pemeliharaan $(\mathrm{g})$

\subsubsection{Retensi Lemak}

Nilai retensi lemak dapat dihitung dengan menggunakan rumus Watanabe et al., (2001):

$$
\mathrm{RL}(\%)=[(\mathrm{F}-\mathrm{I}) / \mathrm{L}] \times 100
$$

Keterangan: $\mathrm{RL}=$ Retensi Lemak $(\%), \mathrm{F}=$ Jumlah kandungan lemak tubuh udang pada akhir pemeliharaan $(\mathrm{g}), \quad \mathrm{I}=$ Jumlah kandungan lemak tubuh udang pada awal pemeliharaan $(\mathrm{g}), \mathrm{L}=$ Jumlah lemak udang yang dikonsumsi selama pemeliharaan $(\mathrm{g})$.

\subsubsection{Parameter Kimia}

Parameter kimia terdiri dari analisis proksimat. Analisis proksimat tubuh udang meliputi kadar protein kasar, lemak kasar, abu, dan air dilakukan pada awal penelitian dan akhir penelitian. Sebanyak 20 g udang dari setiap perlakuan dan ulangan digunakan untuk analisis proksimat tubuh.

\subsubsection{Analisis Data}

Rancangan percobaan yang digunakan adalah rancangan acak lengkap (RAL) dengan 2 perlakuan 2 dan 3 ulangan. Data hasil perhitungan ditabulasi dan dianalisis menggunakan program Microsoft Excel 2013 dan SPSS 22.0. Untuk mengetahui pengaruh perlakuan terhadap setiap parameter yang diuji maka data diuji statistik dengan uji independent sample t-test $(\mathrm{p}=0,05)$ menggunakan SPSS 16.0.

\section{HASIL DAN PEMBAHASAN}

\subsection{Hasil}

Data hasil mengenai rata-rata TSS, VSS, volume flok, nutrien flok, pertumbuhan relatif, laju pertumbuhan harian (LPH), efisiensi pakan, tingkat kelangsungan hidup $(\mathrm{TKH})$, retensi protein dan retensi lemak ditunjukkan pada Tabel 3, 4 dan 5 . Berdasarkan Tabel 3 dapat diketahui bahwa nilai tertinggi TSS terdapat pada akhir pemeliharan dengan sistem bioflok yaitu 261,33 mg/L. Hasil VSS pada akhir pengamatan menunjukkan peningkatan pada perlakuan sistem bioflok yaitu 231,33 mg/L. Hasil volume flok pada akhir pengamatan menunjukkan peningkatan pada perlakuan sistem bioflok yaitu 21,33 mL/L.

Flok yang terbentuk pada perlakuan sistem bioflok memiliki nilai nutrien yang tinggi. Nilai nutrien terdapat pada perlakuan sistem bioflok yaitu memiliki nilai gross energi (GE) mencapai $2619,64 \mathrm{kkal} / \mathrm{kg}$.

Parameter pengamatan yang diukur selama pengamatan ditunjukkan pada Tabel 5. 
Tabel 3. Total suspended solid (TSS), Volatile suspended solid (VSS) dan volume flok yang terbentuk pada media pemeliharaan udang vaname Litopenaeus vannamei selama 28 hari masa pemeliharaan, (-) tidak dilakukan pengukuran.

\begin{tabular}{lcccccc}
\hline \multirow{2}{*}{ Parameter } & \multicolumn{5}{c}{ Perlakuan } \\
\cline { 2 - 7 } & \multicolumn{5}{c}{ C $(40 \%)$} & \multicolumn{3}{c}{ K (40\%) Kontrol } \\
\cline { 2 - 7 } & Awal & Tengah & Akhir & Awal & Tegah & Akhir \\
\hline TSS mg/L & 56,67 & 200,00 & 261,33 & & & \\
VSS mg/L & 51,33 & 173,33 & 231,33 & - & - & - \\
Volume flok mL/L & 10,67 & 14,00 & 21,33 & - & - & - \\
\hline
\end{tabular}

Tabel 4. Komposisi nutrien bioflok yang terbentuk pada media pemeliharaan udang vaname Litopenaeus vannamei selama 28 hari masa pemeliharaan.

\begin{tabular}{lc}
\hline \multicolumn{1}{c}{ Berat kering } & $(\%)$ \\
\hline Protein & 14,35 \\
Lemak & 3,02 \\
Serat Kasar & 12,73 \\
Kadar Abu & 33,42 \\
BETN* & 36,48 \\
GE** & 2619,64 \\
\hline
\end{tabular}

Keterangan : (-) tidak dilakukan pengukuran (perlakuan tersebut tidak diproksimat), BETN* $=$ Bahan ekstrak tanpa nitrogen, GE** = Gross energy 1 gr protein= 5,6 kkal GE, 1 gram lemak =9,4 kkal GE, 1 gram BETN = 4,1 kkal GE. (Watanabe, 1988).

Tabel 5. Parameter pengamatan yang diukur pada pemeliharaan udang vaname Litopenaeus vannamei selama 28 hari masa pemeliharaan.

\begin{tabular}{lcc}
\hline \multirow{2}{*}{ Parameter } & \multicolumn{2}{c}{ Perlakuan } \\
\cline { 2 - 3 } & $\mathrm{C}(40 \%)$ & $\mathrm{K}(40 \%)$ \\
\hline Panjang relatif (\%) & $0,030 \pm 0,002^{\mathrm{b}}$ & $0,019 \pm 0,002^{\mathrm{a}}$ \\
LPH Bobot ${ }^{*}(\%)$ & $9,85 \pm 0,21^{\mathrm{b}}$ & $5,98 \pm 0,73^{\mathrm{a}}$ \\
Efisiensi Pakan (\%) & $37,33 \pm 3,51^{\mathrm{b}}$ & $22,56 \pm 2,48^{\mathrm{a}}$ \\
Kelangsungan Hidup (\%) & $95,45 \pm 1,82^{\mathrm{a}}$ & $92,73 \pm 1,82^{\mathrm{a}}$ \\
Retensi Protein (\%) & $12,03 \pm 1,04^{\mathrm{b}}$ & $5,67 \pm 0,44^{\mathrm{a}}$ \\
Retensi Lemak (\%) & $10,48 \pm 1,71^{\mathrm{b}}$ & $4,88 \pm 1,60^{\mathrm{a}}$ \\
\hline
\end{tabular}

Keterangan: Huruf cetak atas yang berbeda pada baris yang sama menunjukkan pengaruh perlakuan yang berbeda nyata $(\mathrm{P}<0.05)$. Nilai yang tertera merupakan nilai ratarata \pm standard deviasi. LPH Bobot* $=$ Laju pertumbuhan harian bobot.

Berdasarkan Tabel 5 di atas diketahui bahwa pertumbuhan relatif, laju pertumbuhan harian (LPH), efisiensi pakan, tingkat kelangsungan hidup, retensi protein dan retensi lemak pada perlakuan sistem bioflok memberikan nilai lebih tinggi dari perlakuan tanpa sistem bioflok $(\mathrm{P}<0,05)$.

\subsection{Pembahasan}

Hasil penelitian menunjukkan bahwa nilai TSS media air pemeliharaan semakin 
meningkat seiring bertambahnya waktu pemeliharaan. Nilai TSS pada media air pemeliharaan udang vaname sistem bioflok berkisar antara 50 sampai $260 \mathrm{mg} / \mathrm{L}$. Hasil tersebut sesuai dengan nilai TSS yang disarankan untuk budidaya ikan secara indoor dengan teknologi bioflok yaitu 597 $\mathrm{mg} / \mathrm{L}$ dan kolam kontrol tanpa bioflok sebesar 16 mg/L (Azim dan Little, 2008). Hasil penelitian Lorenzo et al. (2015) menunjukkan bahwa nilai TSS pada media pemeliharaan udang vaname sebesar 278.3 mg/L yang diberi perlakuan sumber karbon molase. Schveitzer et al. (2013) menunjukkan bahwa nilai TSS berkisar antara 400 - $600 \mathrm{mg} / \mathrm{L}$ lebih cocok untuk budidaya vaname super intensif karena mampu menjaga produktivitas dan kesetabilan sistem.

Hasil penelitian ini menunjukkan bahwa rata-rata nilai VSS pada perlakuan sistem bioflok lebih tinggi dari pada perlakuan tanpa sistem bioflok. Nilai VSS pada akhir perlakuan sistem bioflok sebesar 231,33 mg/L (Tabel 3). Hasil ini lebih baik dengan hasil penelitian Lorenzo et al. (2015) menyatakan bahwa nilai VSS pada media pemeliharaan udang vanamei sebesar 94.94 mg/L yang diberi perlakuan sumber karbon molase. Tingginya nilai VSS pada perlakuan sistem bioflok dibanding dengan perlakuan tanpa sistem bioflok diduga karena adanya penambahan molase sebagai sumber karbon yang menyebabkan lebih banyak jumlah koloni bakteri total yang terdapat dalam perairan. Walaupun belum ada data yang tersedia yang dapat dianjurkan pada budidaya berbasis bioflok namun VSS dijadikan sebagai parameter utama dan penting bagi keberadaan bioflok pada sistem budidaya teknologi bioflok (De Schryver et al., 2008).

Pembentukan bioflok selama pemeliharaan dapat dilihat dari tinggi rendahnya nilai volume flok (Tabel 3). Volume flok semakin tinggi seiring bertambahnya waktu pemeliharaan dan nilai tertinggi terdapat pada perlakuan bioflok (21 $\mathrm{mL} / \mathrm{L})$. Hasil penelitian Bakar et al. (2015) menyatakan bahwa pemberian sumber karbon pada wadah budidaya ikan lele Clarias gariepinus mampu membentuk formasi flok sebesar $92,5 \mathrm{~mL} / \mathrm{L}$. Volume flok yang baik dalam akuakultur memiliki nilai TSS $>200 \mathrm{~mL} / \mathrm{g}$. (De Schryver et al., 2008). Volume flok yang terbentuk menunjukan bahwa bakteri pada wadah pemeliharaan dapat memanfaatkan molase untuk pertumbuhan dan sebagai sumber energi. Disamping itu untuk pembentukan bioflok juga berkorelasi dengan nitrogen sebagai pembentuk single cell protein (SCP) bakteri selanjutnya membentuk biomassa bakteri atau disebut dengan flok. Flok yang terbentuk tersebut bisa dimanfaatkan udang sebagai pakan alami.

Perlakuan dengan sistem bioflok, nutrien flok yang terbentuk juga berbedabeda tergantung mikroorganisme pembentuk flok tersebut. Komposisi organisme dalam flok akan mempengaruhi struktur bioflok dan kandungan nutrien bioflok (Izquierdo et al., 2006; Ju et al., 2008). Organisme penyusun bioflok tidak hanya bakteri, fungi dan alga saja, namun ditemukan tiga kelompok lain penyusun bioflok seperti rotifer, protozoa dan cacing yang merupakan pakan alami bagi udang dihabitat aslinya (Azim and Litle, 2008). Menurut (De schryver et al., 2008) bioflok mengandung protein, asam lemak tak jenuh, dan lipid yang tinggi sehingga cocok digunakan sebagai pakan untuk udang.

Laju pertumbuhan udang vaname yang dipelihara dalam sistem bioflok lebih tinggi dibandingkan dengan kontrol $(\mathrm{P}<0,05)$. Hasil penelitian menunjukkan bahwa laju pertumbuhan harian bobot udang vaname lebih tinggi pada perlakuan dengan sistem bioflok $(9,85 \%)$ dibandingkan dengan perlakuan kontrol (5,98\%) (Tabel 5). Menurut Crab et al. (2012) sistem bioflok mampu memproduksi protein pakan secara in situ dalam wadah pemeliharaan sehingga flok yang terbentuk dalam wadah pemeliharaan dapat dimanfaatkan oleh udang sebagai nutrisi tambahan. 
Selain meningkatkan pertumbuhan, aplikasi bioflok juga meningkatkan efisiensi pakan. Nilai efisiensi pakan selama pemeliharaan menunjukkan bahwa perlakuan sistem bioflok berbeda signifikan dibandingkan perlakuan tanpa sistem bioflok (Tabel 5). Efisiensi pakan mencapai 37,33\% terdapat pada perlakuan sistem bioflok dan pada perlakuan tanpa sistem bioflok 22,56\%. Hal ini menunjukan bahwa flok yang terbentuk dimanfaatkan oleh udang vaname untuk pertumbuhan karena adanya pakan alami dari flok, flok juga yang terbentuk membuat udang dapat memanfaatkan bakteri sebagai salah satu sumber protein (De Schryver et al., 2008). Prinsipnya, nilai tambah teknologi bioflok ditentukan oleh potensinya sebagai sumber pakan tambahan udang (De Schryver et al., 2008).

Nilai retensi protein dan retensi lemak menggambarkan adanya pemanfaatan nutrisi pakan yang telah dicerna oleh tubuh ikan, diserap, dan disimpan untuk menghasilkan energi (Lovell, 1988). Nilai retensi protein $11,55 \%$ terdapat pada perlakuan yang menggunakan sistem bioflok sedangkan nilai retensi protein pada perlakuan kontrol 5,20\% (Tabel 5). Hal yang sama juga terjadi pada nilai retensi lemak, pada perlakuan menggunakan sistem bioflok lebih tinggi yaitu $11,02 \%$ dibandingkan kontrol yang hanya $(5,33 \%) \quad(\mathrm{P}<0,05)$. Hasil ini sesuai dengan sebelumnya bahwa sistem bioflok dapat meningkatkan efisiensi pakan, retensi protein, dan kinerja pertumbuhan pada udang vanamei $L$. vannamei (Wasielesky et al., 2006) dan P. monodon (Arnold et al., 2009). Hal ini terjadi karena terdapat nutrisi tambahan berupa protein dari flok yang terbentuk selain protein dari pakan buatan yang diberikan. Flok yang terbentuk diduga dimanfaatkan oleh udang sebagai nutrisi tambahan sehingga dapat meningkatkan pertumbuhan.

Perlakuan dengan sistem bioflok tidak menunjukkan perbedaan terhadap tingkat kelangsungan hidup udang vaname dengan perlakuan kontrol $(\mathrm{P}<0,05)$. Selama
28 hari masa pemeliharan, kedua perlakuan memiliki nilai kelangsungan hidup sangat tinggi (Tabel 5). Pada perlakuan pakan protein $40 \%$ sistem bioflok memiliki nilai tingkat kelangsungan hidup mencapai $(95,45 \%)$. Sesuai dengan pendapat Riani et al. (2012) menyatakan bahwa bioflok mampu meningkatkan derajat kelangsungan hidup sebesar $92 \%$ pada udang vanamei. Hal ini menunjukkan bahwa perlakuan dengan sistem bioflok yang diberikan tidak mengganggu proses fisiologis dan tingkah laku udang, serta diduga dapat meningkatkan kondisi kesehatan. Bakteri-bakteri penyusun bioflok, salah satunya Bacillus sp diketahui juga dapat mengakumulasikan senyawa Poly$\beta$-hydroxybutyrate (PHB) yang diketahui dapat menghambat pertumbuhan dari berbagai jenis patogen (Michaud et al., 2006). PHB merupakan produk polimer intraseluler, polimer ini diduga mempunyai efek pencegahan dan pengobatan terhadap infeksi Vibrio serta manfaat prebiotik dalam akuakultur (Defoirdt et at., 2007; de Schryver et al., 2008). Adanya kandungan PHB pada bioflok diangap dapat meningkatkan sistem imun udang sehingga memberi dampak positif terhadap kelangsungan hidup udang vaname.

\section{KESIMPULAN}

Kegiatan pendederan udang vaname dengan sistem bioflok dapat memberikan pertumbuhan dan efesiensi pakan yang lebih tinggi dan berbeda signifikan dibandingkan kontrol $(\mathrm{P}<0,05)$.

\section{UCAPAN TERIMA KASIH}

Penelitian ini dibiayai oleh Dikti melalui proposal Penelitian Institusi (PI) PKSPL, LPPM-IPB tahun 2015. Terima kasih disampaikan pada Program Keahlian Ilmu Perikanan Diploma, Institut Pertanian Bogor yang telah membantu selama pelaksanaan penelitian ini. 


\section{DAFTAR PUSAKA}

American Public Health Association (APHA). 2005. Standard methods for examination of water and waste water, $21^{\text {st }}$ ed. APHA. Washington. DC. $541 \mathrm{p}$.

Avnimelech, Y. 1999. Carbon/nitrogen ratio as a control element in aquaculture sytems. Aquaculture, 176:227-235.

Avnimelech, Y. and G. Ritvo. 2003. Shrimp and fish pond soils: processes and management. Aquaculture, 220:549567.

Avnimelech, Y. 2006. Bio-filters: the need for a new comprehensive approach. Aquaculture, 34:172-178.

Avnimelech, Y. 2007. Feeding with microbial flocs by tilapia in minimal discharge bio-flocs tecnology ponds. Aquaculture, 264:140-147.

Avnimelech, Y. 2012. Biofloc technology- a practical guide book, $2^{\text {nd }}$ ed. United States, The World Aquaculture Society. 272p.

Azim, M.E. and D.C. Litle. 2008. The biofloc technology (BFT) in indoor tanks: Water quality, biofloc composition, growth and welfare of Nila tilapia (Oreochromis niloticus). Aquaculture, 283:29-35.

Arnold, S.J., F.E. Coman, C.J. Jackson, and S.A. Groves. 2009. High intensity, zero waterexchange production of juvenile tiger shrimp, Penaeus monodon: an evaluation of artificial substrates and stocking density. Aquaculture, 293:42-48.

Bakar, N.S.A., N.M. Nasir, F. Lananan, S.H. A. Hamid, S.S. Lam, and A. Jusoh. 2015. Optimization of $\mathrm{C} / \mathrm{N}$ ratios for nutrient removal in aquaculture system culturing African catfish, Clarias gariepinus utilizing bioflocs technology. International Biodeterioration \& Biodegradation, 10:1-7.

Defoirdt, T., D. Halet, H. Vervaeren, N. Boon, T. Van de Wiele, P. Sorgeloos,
P. Bossier, and W. Verstraete. 2007. The bacterial storage compound of poly-b-hydrobutyrateprotects Artemia fransiseana from pathogenic Vibrio campbellii. Environ. Microbiol., 9 (2):445-452.

De Schryver, P., R. Crab, T. Defroidt, N. Boon, and Verstreate. 2008. The basics of bio-flocs technology: The added value for aquaculture. Aquaculture, 277:125-137.

Ekasari, J. 2008. Biofloc technology: The effect different carbon source, salinity and the addition of probiotics on the primary nutritional value of thebioflocs. Thesis. Ghent. Ghent University, Belgium. 72p.

Goddard, S. 1996. Feed management in intensive aquaculture. Chapman and Hall. New York. 194p.

Huisman, E.A. 1987. The principles of fish culture production. Department of Aquaculture, Wageningen University. The Netherlands. $100 \mathrm{p}$.

Izquierdo, M., L. Forster, S. Divakaran, L. Conquest, O. Decamp, and A. Tacon. 2006. Effect of green and clear water and lipid source on survival, growth and biochemical composition of Pacific white shrimp Litopenaeus vannamei. Aquaculture Nutrition 12: $192-202$.

Ju, Z.Y., L. Forster, L. Conquest, W. Dominy, W.C. Kuo, F.D. Horgen. 2008. Determination of microbial community structures of shrimp floe cultures by biomarkers and analysis of floe amino acid profiles. Aquaculture Research, 39:118-133.

Lorenzo, M.A.D., R. Schveitzer, C.M.D.E. Santo, E.W.S. Candia, J.L.P. Mourino, E.C. Legarda, WQ. Seiffert, and FDN. Vieira. 2015. Intensive hatchery performance of the Pacific white shrimp inbiofloc system. Aquacultur Engineering, 67:53-58. 
Lovell, T. 1988. Nutrition and feeding of fish. Van Nostrand Reinhold. New York. 91p.

Michaud, L., J. Blancheton, V. Bruni, and R. Piedrahita. 2006. Effect of particulate organik carbon on heterotrophic bacterial populations and nitrification efficiency in biological filters. Aquaculture engineering, 34:224-233.

Riani, H., R. Rostika, dan W. Lili. 2012. Efek pengurangan pakan terhadap pertumbuhan udang vaname Litopenaeus vannamei PL-21 yang diberi bioflok. J. Perikanan dan Kelautan, 3:207-211.

Schveitzer, R., R. Arantes, P.F.S. Costodio, C.M.D.E. Santo, L.V. Arana, W.Q. Seiffert, E. R. Andeatta. 2013. Effect of different biofloc levels on microbial activity, water quality and performance of Litopenaeus vanname $i$ in a tank system operated with no water exchange. Aquaculture Engineering, (56): 59-70.

Tacon, A, G. J. 2000. Shrimp feeds and feeding regime in zero exchange outdoor tanks. Global Aquaculture Advocate, 3(2): 15-16.

Takeuchi, T. 1988. Laboratory work chemical evaluation of dietary nutrient. Dalam Watanabe T, editor. Fish Nutrition and Marinculture. Tokyo. JICA Kanagawa International Fisheries Training Centre. 179-225 p. Watanabe, O.W., S.C. Ellis, and J. Chaves. 2001. Effect of dietary lipid and energy to protein ratio on growth and feed utilization of juvenile mutton snapper Lutjanus analis fed isonitrogenous diets at two temperature. $J$. of The World Aquaculture Society, 32(1):30-40.

Watanabe, T. 1988. Fish nutrition and mariculture. JICA Text Book. The GeneralAquaculture Course. Departemen of Aquaculture Bioscience: Tokyo University of Fisheries. ACM. Jepang. 315p.

Wasielesky, W., H. Atwood, A. Stokes, and C.L. Browdy. 2006. Effect of natural production in a zero exchange suspended microbial floc based superintensive culture system for white shrimp Litopenaeus vannamei. Aquaculture, 258:396-403.

$\begin{array}{ll}\text { Diterima } & : 15 \text { April } 2017 \\ \text { Direview } & : 25 \text { April } 2017 \\ \text { Disetujui } & : 23 \text { Maret } 2018\end{array}$

